\title{
Role of non-governmental organizations in global health
}

\author{
Suguna Anbazhagan*, Surekha A.
}

Department of community health, St. Johns medical college, Bangalore, India

Received: 16 October 2015

Revised: 21 October 2015

Accepted: 11 December 2015

\section{* Correspondence:}

Dr. Suguna Anbazhagan,

E-mail: sugucommed87@gmail.com

Copyright: ( ) the author(s), publisher and licensee Medip Academy. This is an open-access article distributed under the terms of the Creative Commons Attribution Non-Commercial License, which permits unrestricted non-commercial use, distribution, and reproduction in any medium, provided the original work is properly cited.

\begin{abstract}
Global health also refers to 'inherently global health issues', that is, health-determining phenomena that transcend national borders and political jurisdictions, such as globalization and climate change. NGOs include charitable and religious associations that mobilize private funds for development, distribute food and family planning services and promote community organization. They also include independent cooperatives, community associations, water-user societies, women's groups and pastoral associations. To contribute to shared global health objectives, NGOs should work in close partnership with a wide array of international agencies and institutions to shape global health policies and to fund, implement, and evaluate programs. Non-governmental organizations are a basic element in the representation of the modern world. And their participation in international organizations is in a way a guarantee of the latter's political legitimacy. From the stand point of global democratization, we need the participation of international public opinion and the mobilizing powers of non-governmental organizations.
\end{abstract}

Keywords: NGOs, Global health

\section{INTRODUCTION}

Global health is essential for development. A major issue is the inequitable distribution of research efforts and funds directed towards populations suffering the world's greatest health problems. This imbalance is fostering major attempts at redirecting research to the health problems of low and middle income countries. This paper highlights some of the prevalent thinking and is intended to encourage new thinking on how NGOs can further this role.

The objective of this review was to know about the role of various NGOs in global health.

\section{Nongovernmental organizations}

World Bank defines NGO as "The diversity of NGOs strains any simple definition. They include many groups and institutions that are entirely or largely independent of government and that have primarily humanitarian or cooperative rather than commercial objectives. They are private agencies in industrial countries that support international development; indigenous groups organized regionally or nationally; and member-groups in villages. NGOs include charitable and religious associations that mobilize private funds for development, distribute food and family planning services and promote community organization. They also include independent cooperatives, community associations, water-user societies, women's groups and pastoral associations. Citizen groups that raise awareness and influence policy are also NGOs."

According to the Human Development Report, there were in 2002 over 37,000 NGOs in the world, a growth of $19.3 \%$ from 1990. Their purposes differ but overall two categories dominate: economic development and infrastructure $(26 \%)$ and research $(23 \%)$. 


\section{Goals \& strategies of NGOs}

NGOs have following characteristics:

1 Engaging in suffering relief activities

2 Promoting interest of the poor

3 Protecting the environment

4 Providing basic social services

5 Advocating community development

Key issues addressed by NGOs include:

Key Issues

1 Environment

2 Labor Standard

3 Poverty

4 Globalization

5 Animal Rights

Three major types of global health actors:

1 Multinational organizations

A. Organizations within the UN system relevant to health.

B. Organizations outside of the UN system relevant to health.

2 Bilateral - government-to-government or to sub government levels.

3 Non-governmental organizations (NGOs).

\section{NGOs defined by their extraordinary diversity}

- Non-profit and profit-based

- Religious and secular

- Narrow and broad scope programs

- Wealthy and shoe-string operations

- Big NGOs are called BINGOs

- Well paid, marginally paid and volunteer staff

- Long- and short-term commitments

- Single-country, multi-country and regional focus

- Single problem and multi-problem focus

- Single sector and multi-sector focus

- Emergency relief and development focus

\section{Charitable (secular) organizations}

- Oxfam

- CARE

- Save the Children/UK (\& US)

- International Red Cross

- Doctors without Borders

- Project Hope

- International Rescue Committee

- CARE

- Freedom from Hunger

- Child Family Health International

- Doctors for Global Health

\section{Faith-based organizations (FBOs)}

- Catholic Relief Services

- Christian Aid

- Lutheran World Relief

- Unitarian Universalist Service Society

\section{Philanthropic foundations}

- Bill \& Melinda Gates

- Atlantic Philanthropies

- Carnegie

- Rockefeller

- Clinton Global Initiative

- Carlos Slim

- Josiah Macy, Jr.

- Kellogg

- Ford

- MacArthur

- Seva

Membership organizations (including their international /global health sections).

- Global Health Council

- American Public Health Association

- American Academy of Family Physicians

- American Academy of Paediatrics

- Rotary International

- Global Health Education Consortium

\section{Consulting / contracting organizations (PVOs)}

- John Snow International

- Management Sciences for Health

- Abt Associates

- IntraHealth International

- Family Health International

- Academy for Educational Devt

Rapid increase in global health centres \& programs

- A 20010 CUGH survey found $>200$ such Programs.

- Involvement in training, research, service.

- Some major university programs

- Duke University

- Emory University

- Oxford University

- Harvard University

- Vanderbilt University

- University of Toronto

- University of Washington

- Johns Hopkins University

- Univ. of Calif. at San Francisco

- London School Hygiene \& Tropical 


\section{Examples of work done by Philanthropic Foundations}

Bill and Melinda Gates Foundation, Carlos Slim, \& others

- Collectively these foundations have increased global spending for

HIV/AIDS (from \$250M to \$7B 1996-2004).

\section{Clinton global initiative (CGI)}

Involving the private sector and getting participant commitments for involvement.

- If no follow-up by a CGI participant, no further invitation to the CGI.

- Increased investment in research and development.

- 10/90 gap: Only $10 \%$ of the world's R\&D is spent on problems affecting $90 \%$ of the population.

\section{Rotary clubs and polio eradication}

- A success, maybe, since small pockets of prevalence are resistant to immunization for religious or other reasons.

Foundation can significantly influence government and inter-governmental Organizations.

Gates - grand challenges in global health

- Create new vaccines

- Improve childhood vaccines

- Cure latent and chronic infections

- Improve nutrition to promote health

- Improve drug treatment of infectious diseases

- Control insects that transmit agents of disease

- Measure disease and health status accurately and economically in developing countries

- And perhaps, improve health systems and their human resources.

\section{Non-profit NGOS}

\section{Strengths}

- Great variety of programs to meet many needs.

- Potentially very flexible with fast response times.

- Volunteers \& non- profit status lower operational costs.

- Staff with high personal commitment to providing help.

- Can easily relate to host country organizations.

- Less tainted by association with government.

- Lower corruption potential.
- Campaigns help educate the public to human needs.

\section{Potential critiques}

- Limited accountability and ability to evaluate effectiveness.

- High motivation not necessarily matched by expertise.

- May have high volunteer turnover and short stays.

- May compete or not coordinate actions with similar NGO and country programs.

- Programs often narrowly focused on specific diseases or problems, with limited attention to infrastructure development.

- Specific diseases and problems are more 'marketable' to donors.

- Program results are easier to document with limited, measurable, though not necessarily meaningful, objectives, e.g., meals delivered, educational talks given, persons trained, medicines handed out, books delivered.

Many organizations interested in and advocate for global health but do not provide direct assistance.

- Global Health Council (in reorganization as of 2013).

- UN Association of the USA

- Council on Foreign Relations

- Returned Peace Corps Volunteers

- Commissioned Officers Association

- Academic Alliances in Global Health

- Global Health Education Consortium

- Consortium of Universities for Global Health

- American Public Health Association \& many others.

\section{Global health}

Global health also refers to 'inherently global health issues', that is, health-determining phenomena that transcend national borders and political jurisdictions, such as globalization and climate change.

Many U.S. based international non-governmental organizations (NGOs) are actively engaged in international health projects. The relief agency CARE, for example, participates in a joint CARE-CDC Health Initiative (CCHI), which makes best use of CDC's technical and scientific expertise and CARE's on-theground capabilities to address critical health issues in countries around the world. The eradication of Guinea worm and the prevention of river blindness throughout the world top the Atlanta-based Carter Center's list of global health concerns. Through The Carter Center's efforts, community-based intervention programs primarily in Africa have greatly reduced the burden of 
these diseases among some of the world's poorest people. Combining forces with the CDC, WHO, UNICEF, and others, The Carter Center helps make the idea of publicprivate partnership in global health a reality. ${ }^{2}$

\section{ROLE OF ngos IN GLOBALIZING WORLD}

Non-governmental organizations are a basic element in the representation of the modern world. And their participation in international organizations is in a way a guarantee of the latter's political legitimacy. From the stand point of global democratization, we need the participation of international public opinion and the mobilizing powers of non-governmental organizations.

Non-governmental organizations (NGOs) in the health sphere have gained strength, momentum and numbers over time. The Director General of WHO,1973-1988, recognized the ability of NGOs to influence policy makers, as noted by Narayan, Wise, and Ghebrehiwet: "Dr. Mahler, Director General of WHO at the time, publicly states that it was the non- governmental organizations (NGOs) who pressed WHO strongly to move beyond a disease-focused, expert-dependent, techno-management approach, based on the dominant system of medicine, to one wherein community participation, inter-sect oral coordination and appropriate technology were important." A recent (2010) acknowledgement by Laaser and Epstein of the power of NGOs in the health arena states that the fourth phase of the internationalization of health "is characterized by the growing influence of health-related, non-governmental organizations (NGOs)..." which include those in the arena of public health, such as the World Federation of Public Health Associations (WFPHA), the International Union for Health Promotion and Education (IUHPE), the International Association of National Public Health Institutes (IANPHI), national and regional public health associations, and national and regional associations of schools of public health.

In May 1977 the World Federation of Public Health Associations (WFPHA) accepted an invitation from the World Health Organization (WHO) and the United Nations Children's Fund (UNICEF) to develop a position paper representing views of nongovernmental organizations about primary health care for presentation at the International Conference on Primary Health Care to be held in September 1978 in Alma-Ata, Kazakh, SSR. The WFPHA consulted a large number of nongovernmental organizations (NGOs), both those in official relationship with WHO and UNICEF and many other interested NGOs, national and international. In the field of health, NGOs have long helped to set standards for practice, training, and continuing education and to define the role of health workers in national programs. Others have concentrated on a particular disease or activity (e.g. cardiovascular diseases, leprosy, tuberculosis, programs for the disabled, etc).
The diverse programs and competencies of numerous organizations, not directly involved in health care, also contribute in one way or another to total human development. They include projects to improve nutrition, food production, and housing; provide safe water; promote literacy; provide educational and other instructional materials; further community development; provide training in a broad range of skills; protect the environment; etc. In short, they are helping to create conditions conducive to the protection, promotion, and maintenance of health and the prevention of illness.

Recent years have seen a growing capacity of nongovernmental organizations to develop patterns of cooperation among themselves locally, nationally, and internationally, for consultation and exchange of information, or for joint action.

\section{Role of NGOs in primary health care: ${ }^{4}$}

1. At all stages in the development of primary health care programs, NGOs can be effective. Recognition by government of the contributions NGOs can make in support of primary health care will ensure maximum benefits of these contributions to the national health program.

2. NGOs can work for greater understanding and positive attitudes toward primary health care by:

a) Promoting dialogue both within and among NGOs;

b) Sustaining dialogue with governmental authorities;

c) Providing information and creating new ways of explaining primary health care to the general public and

d) Strengthening means of communication to accomplish this.

3. NGOs can assist national policy formation in the areas of health care and integrated human development. They can present health care needs based on their contacts with communities, and they can also interpret primary health care plans to relevant donor agencies.

4. NGOs can establish means for greater collaboration and coordination of primary health care activities. This can be done among NGOs and between them and governments, locally, nationally, and internationally.

5. NGOs can contribute to primary health care in many ways through program implementation. They can:

a) Provide assistance to develop and/or strengthen local NGO capabilities and activities with particular attention to local community development groups; 
b) conduct reviews and assessment of existing health and development programs and assist communities in the exercise of their own role in such reviews; a greater emphasis on evaluative techniques will render all new programs more accountable to real community needs;

c) Develop innovative programs placing primary health care in the context of comprehensive human development;

d) Ensure that their existing programs and new initiatives promote full participation by individuals and communities in the planning, implementation, and control of these programs;

e) Expand their training efforts to respond to the needs of primary health care programs. e.g., training of health workers, supervisors, administrators, planners, and various agricultural and development workers; included would be training schemes which build on the skills of traditional healers and midwives;

f) Extend their efforts to develop locally sustainable and appropriate health technologies and use of resources, with particular attention to energy, water, agriculture, sanitation, and medical care;

g) Contribute to the creation of new and effective methods of health education which enable both individuals and communities to assume greater responsibility for their own health;

h) Recognize the essential role of women in health promotion and in the full range of community development concerns;

i) Further extend their capacity to work with poor, disadvantaged, and remote populations, enabling them to break the cycle of deprivation and in this way contribute to the search for greater social justice.

\section{Global health diplomacy}

To engage in the discourse of global health diplomacy, NGO diplomats are immediately presented with two challenges: to convey the interests of larger publics and to contribute to inter-state negotiations in a predominantly state-centric system of governance that are often diluted by pressures from private interests or mercantilist self-interest on the part of the state itself. ${ }^{6}$ NGOs are an important part of global health diplomacy and their strong presence on the global stage represents one of the trends that have been attributed to the emergence of the field itself. ${ }^{7}$ Frist (2007: 225) notes that 'health diplomacy can mean building a culture of discourse and collaboration between governments and those NGOs that operate at the grass-roots, community level and have the greatest access to people in need'. Whether and how such ideals have been enacted has not yet received systematic study in the global health diplomacy literature. ${ }^{8}$ The most prominent allusion to NGO contributions to global health diplomacy is their role in injecting ideas into dialogue. Fidler (2008) asserts, although implicitly, that governments represent power in diplomacy whereas NGOs represent ideas and knowledge. ${ }^{9}$ Canadian NGOs engaged in the FCTC negotiations by gathering and brokering knowledge to delegations - knowledge about the technical process of policy-making as well as about the substantive topic of tobacco control-while working to enhance the representation of NGOs from different regions of the world

\section{NGOs in schools of public health (SPH)}

A few other organizations have provided direct funding recently for the development and capacity building of SPHs, although there often is a need for additional funding partners for particular aspects of a school. One well-documented example is BRAC (formerly Bangladesh Rural Advancement Committee), the largest NGO in the world, ${ }^{10}$ and the establishment of the James P. Grant School of Public Health in 2004. Great strides have been made over the last century to supply a trained public health workforce. Much of this work has been accomplished through direct involvement and funding by NGOs, but the lack of funding and initiative remain a global issue. More government and NGO funding is needed to continue establishment and expansion of schools and programs of public health education.

\section{Role of NGOS in global health research}

NGOs are contributing at all stages of the research cycle, fostering the relevance and effectiveness of the research, priority setting, and knowledge translation to action. They have a key role in stewardship (promoting and advocating for relevant global health research), resource mobilization for research, the generation, utilization and management of knowledge, and capacity development. Yet, typically, the involvement of NGOs in research is downstream from knowledge production and it usually takes the form of a partnership with universities or dedicated research agencies.

COHRED (Council for Health Research in Development) works in partnership with WHO, the World Bank and other organizations to strengthen the role of health research at the country level. The Canadian Coalition for Global Health Research

(CCGHR) is developing into a network of health researchers, funding agencies, NGOs, and other stakeholders committed to support the pursuit of effective global health research by ensuring that all these groups work together as effectively as possible with researchers in developing countries.

NGOs often play a critical role in interpreting the evidence and translating its relevance for local communities. Inevitably the level of involvement by the community depends on relevance and opportunity for action and advocacy. Assessing and evaluating 
opportunities for advocacy and action occur as NGOs work with communities on these issues. Effective involvement of the community and its participation is a "matter of reciprocity and continuing dialogue in which participation takes different forms and influences change in several directions."11

Medecins sans Frontieres (MSF) was the first NGO to both provide emergency medical assistance and publicly bear witness to the plight of the populations they served. MSF is at the forefront of emergency health care as well as care for populations suffering from endemic diseases and neglect. MSF has undertaken an initiative on drugs for neglected infectious disease which combines advocacy, research and capacity development, and networking. In contrast with private sector research, it is need-driven rather than profit-driven. Research for International Tobacco Control (RITC) is an International Secretariat based at IDRC headquarters (Ottawa) that fund multidisciplinary tobacco control research projects in developing countries. There is a need to more effectively include NGOs in all aspects of health research in order to maximize the potential benefits of research. ${ }^{12}$

\section{CONCLUSION}

The scope and intensity of global health challenges ensures that no single country or agency can work alone to meet them. To contribute to shared global health objectives, NGOs should work in close partnership with a wide array of international agencies and institutions to shape global health policies and to fund, implement, and evaluate programs.

\section{ACKNOWLEDGEMENTS}

Authors would like to acknowledge their ProfessorsAnat, Dan, Nadav, Gal.

Funding: No funding sources Conflict of interest: None declared

Ethical approval: Not required

\section{REFERENCES}

1. UNDP: Human Development Report, Deepening Democracy in a Fragmented World. New York. 2002.
2. Global health partnerships: Centre for disease control and development. Available from URL: http://www.cdc.gov/globalhealth/partnerships.htm. Accessed on 1st of October 2015.

3. Narayan T, Wise M, Ghebrehiwet. NGO coalitions for global health promotion. Available from URL: http://www.phmovement.org/pha2/issues/documents / ngocoalitionsforglobalhealthpromotion. Accessed on 1 st of October 2015.

4. Laaser U, Epstein L. Threats to global health and opportunities for change: A new global health. Public health reviews. 2010;(32):54-89.

5. World Federation of Public Health Associations: Non-Governmental Organizations and Primary Health Care Position Paper - Passed by the WFPHA General Assembly. 1978.

6. Lencucha $\mathrm{R}$, Kothari A. The role of nongovernmental organizations in global health diplomacy: negotiating the Framework Convention on Tobacco Control. Health Policy and Planning. 2010.

7. Adams V, Novotny TE, Leslie H. Global health diplomacy. Medical Anthropology. 2008;( 27):31523.

8. Frist WH. Medicine as a currency for peace through global health diplomacy. Yale Law \& Policy Review. 2007;(26):209-29.

9. Fidler DP. Global health jurisprudence: a time of reckoning. The Georgetown Law Journal. 2008;(96):393-412.

10. World Health Organization. Public health schools: six portraits. Bulletin: World Health Organization. 2007;(85):907-9.

11. Neufeld V, Johnson N. Forging Links for health: perspectives from the Council on Health Research for Development Ottawa: IDRC. 2001.

12. Delisle H, Roberts JH. The role of NGOs in global health research for development. Health Research Policy and Systems. 2005;3:3.

Cite this article as: Anbazhagan S, Surekha A. Role of non-governmental organizations in global health. Int J Community Med Public Health 2016;3:17-22. 